ПРОБЛЕМИ ЕКОНОМІЧНОЇ І СОЦІАЛЬНОЇ ПОЛІТИКИ

УАК: 336.14(477.44)

DOI: $10.37128 / 2411-4413-2019-9-5$

\section{ПОРЯДОК ФОРМУВАННЯ ТА ВИКОРИСТАННЯ МІСЦЕВИХ БЮДЖЕТІВ ОТГ ВІННИЦЬКОÏ ОБЛАСТІ ${ }^{\odot}$}

\author{
ПРОНЬКО Л.М., \\ кандидат економічних наук, доцент \\ кафедри адміністративного \\ менеджменту \\ та альтернативних джерел енергї, \\ СЕМЕНЕНКО В.В., \\ кандидат наук дерэсавного управління, \\ доцент кафедри адміністративного \\ менеджменту та альтернативних \\ джерел енерхії \\ Вінницький національний \\ аграрний університет \\ (м. Вінниця)
}

У статті розглянуто порядок формування та виконання місиевих бюджетів ОТГ Вінницької області. Визначено досягнення реформи місиевого самоврядування щодо ефективності управління бюджетними ресурсами об'єднаних територіальних громад. Проведено аналіз фінансової спроможності бюджетів об'єднаних територіальних громад області. Виокремлено проблемні аспекти фінансового забезпечення виконання функцій органами місцевої влади. Запропоновано шляхи удосконалення територіальної організації влади на засадах децентралізаџії та побудови фінансово самодостатніх територіальних громад.

На сьогодні фінансова самостійність місиевих бюджетів ОТГ передбачена відповідними правовими нормами Бюджетного кодексу Украӥни. Із реалізачією окремих кроків бюджетноподаткової децентралізаиії також було розиирено фінансову самостійність місиевих бюджетів через установлення єдиних нормативів відрахувань від загальнодержавних податків; скасування системи індикативного планування Міністерством фінансів України показників місцевих бюджетів; формування єдиного кошика доходів загального фонду та розширення джерела його наповнення; формування та введення в дію системи вирівнювання податкової спроможності території тощо.

Ключові слова: ОТГ, місцеві бюджети, бюджетні надходження, видаткові зобов'язання, міжбюджетні трансферти, бюджетне регулювання, бюджетна децентралізація.

Рис.: 1. Літ.: 12.

\title{
ORDER OF FORMATION AND USE OF LOCAL BUDGETS OF UTC IN VINNYTSIA REGION
}

PRONKO Lyudmila, PhD, associate professor, Department of administrative management and alternative energy sources

SEMENENKO Viktor, $P h D$, associate professor, Department of administrative management and alternative energy sources Vinnitsa National Agrarian University

(Vinnytsia)

The article analyzes the implementation of the local budgets of the UTC of the Vinnytsia region. The achievements of the local self-government reform in terms of the effectiveness of management of the budget resources of the united territorial communities were determined. An analysis of the financial capacity of the budgets of the joint territorial communities of the region. The problematic aspects of the financial provision of the execution of functions by the local authorities are singled out. The ways of improving the territorial organization of power on the principles of decentralization and construction of financially selfsufficient territorial communities are proposed. 
Currently, financial autonomy of local budgets of UTC is provided by the relevant legal norms of the Budget Code of Ukraine. The implementation of individual steps of fiscal decentralization also expanded the financial autonomy of local budgets through: the establishment of uniform norms of deductions from national taxes; the difference between the indicative planning system of the local budgets of the Ministry of Finance of Ukraine; formation of a single basket of general fund revenues and expansion of the source of its filling; formation and putting into operation of the system of equalization of the tax capacity of the territory, etc.

Key words: UTC, local budgets, budget revenues, expenditures, intergovernmental transfers, budget regulation, budget decentralization.

Fig.: 1. Lit.: 12.

\title{
СИСТЕМА ФОРМИРОВАНИЯ И ИСПОЛЬЗОВАНИЯ МЕСТНЫХ БЮДЖЕТОВ ОТО ВИННИЦКОЙ ОБЛАСТИ
}

\author{
ПРОНЬКО Л.Н., \\ кандидат экономических наук, доцент кафедры административного \\ менеджмента и альтернативных источников энергии, \\ Винницкий национальный аграрный университет \\ СЕМЕНЕНКО В.В., \\ кандидат наук государственного управления, \\ доцент кафедры административного \\ менеджмента и альтернативных источников энергии, \\ Винницкий национальный аграрный университет
}

(2. Винница)

В статье рассмотрена система формирования выполнения местных бюджетов ОТО Винницкой области. Определено достижение реформы местного самоуправления в части эффективности управления бюджетными ресурсами объединенных территориальных общин.

$\because$ Проведенный анализ финансовой возможности бюджетов объединенных территориальных общин области Выделено проблемные аспекты финансового обеспечения выполнения функиий органами местной власти. Предложены пути усовершенствования территориальной организации власти на принципах децентрализащии и построения финансово самодостаточных территориальных общин.

На сегодня финансовая самостоятельность местных бюджетов ОТГ предусмотрена соответствуюшими правовыми нормами Бюджетного кодекса Украины. С реализачией отдельных шагов бюджетно-налоговой децентрализации также была расширена финансовая самостоятельность местных бюджетов через: установление единственных нормативов отчислений от общегосударственных налогов; отмену системы индикативного планирования Министерством финансов Украины показателей местных бюджетов; формирование единственной корзины доходов общего фонда и расширения источника его наполнения; формирование и введение в действие системы выравнивания налоговой возможности территории и тому подобное.

Ключевые слова: ОТО, местные бюджеты, бюджетные поступления, расходные обязательства, межбюджетные трансферты, бюджетное регулирование, бюджетная децентрализация.

Рис.: 1. Лит.: 12.

Постановка проблеми. Місцеві бюджети ОТГ Вінницької області є важливою складовою фінансової системи держави. Їхнє ефективне функціонування, зокрема належний перерозподіл фінансових ресурсів місцевого самоврядування створює передумови для успішної діяльності не лише підприємств та установ окремого населеного пункту, ОТГ, району, області, регіону, але й країни загалом.

На жаль, останнім часом у більшості місцевих бюджетів ОТГ спостерігається низький рівень власних та закріплених джерел доходів, що не дозволяє забезпечити достатню фінансову незалежність муніципалітетів. Крім того, місцеві бюджети нині не фінансують навіть найнеобхідніших потреб місцевих громад та місцевих територій.

Аналіз останніх публікацій за проблематикою. Питання виконання місцевих бюджетів досліджували такі науковці, як Артус М.М.[1], Хижа Н.М.[1], Васильєва Н.В. [3], Гринчук Н.М. [3], Дерун Т.М. [3], Далєвська Т. [4], Пелехата О.В. [8], Пронько Л.М. [12], Старостенко Г.Г. [10], Булгаков Ю.В.[10], Овчаренко Т. [11], С.І. Юрій та багато інших вчених.

Віддаючи належне значному доробку науковців та враховуючи важливість результатів останніх, необхідно зазначити, що і досі в умовах децентралізації влади в Україні актуальним 
залишається питання удосконалення законодавчого забезпечення процесу формування фінансовоспроможних територіальних громад, що виникають у процесі їх добровільного об'єднання.

Формулювання цілей статті. Метою статті $\epsilon$ дослідження порядку формування та виконання місцевих бюджетів ОТГ у Вінницькій області та пошук шляхів підвищення рівня їхньої фінансової спроможності.

Виклад основного матеріалу дослідження. Запровадження нового механізму бюджетного регулювання змінило систему тотального збалансування всіх місцевих бюджетів на горизонтальне вирівнювання податкоспроможності територій залежно від рівня надходжень на одного жителя. Значна сума бюджетних коштів залишається в повному розпорядженні місцевих органів влади. Реформа міжбюджетних відносин стимулює територіальні громади ефективніше наповнювати свої кошториси, переходити на самозабезпечення й ощадно планувати свої видатки. Місцева влада самостійно вирішує, на які потреби витрачати бюджетні кошти, що особливо важливо для розвитку об'єднаних територіальних громад [12].

Економічна сутність бюджету полягає в розподілі й перерозподілі валового внутрішнього продукту між галузями економіки, верствами населення і територіями 3 метою підвищення ефективності економіки та добробуту громадян. За його допомогою держава надає суспільству блага й послуги, які істотно впливають на рівень добробуту та якість життя. До таких благ належать оборона країни, національна безпека і правопорядок, благоустрій, захист довкілля, освіта, охорона здоров'я, наука, культура тощо [10, с. 74].

Згідно із Бюджетним кодексом України (далі - БКУ), місцеві бюджети - це обласні, районні бюджети та бюджети місцевого самоврядування. Бюджети місцевого самоврядування - бюджети територіальних громад сіл, їхніх об’єднань, селищ, міст (у тому числі районів у містах), бюджети об’єднаних територіальних громад, що створюються згідно із законом і перспективним планом формування територій громад [2].

Місцеві бюджети, в тому числі бюджети об'єднаних територіальних громад, є самостійними і не входять до Державного бюджету України та інших місцевих бюджетів.

Бюджет впливає на рівень ефективності суспільного відтворення через різні форми вартісних відносин, впливаючи на економічні інтереси суб'єктів суспільства [1]. Саме через місцеві фінанси формуються певні відносини органів самоврядування практично 3 усіма підприємствами, установами, що розміщені на їхній території, і населенням цієї території [8, с. 10].

Проведемо дослідження порядку формування та використання бюджетів в об'єднаних територіальних громадах Вінницької області.

Так, за I півріччя 2018 року до загального фонду місцевих бюджетів Вінницької області надійшло 3552,6 млн грн. Порівняно з відповідним періодом минулого року приріст склав $26.4, \%$, або 741,0 млн грн. Обсяг додатково одержаних доходів ( понад 105 \%) склав 374,6 млн грн. Такі результати вдалося досягти розширенням бази оподаткування за рахунок податку на доходи фізичних осіб, а також підвищенням якісного рівня адміністрування платежів до своїх бюджетів, за рахунок застосування мотиваційних механізмів, забезпечених децентралізацією. I, відповідно, громади тепер можуть заробити значно більше власних коштів, ніж вони мали до того, як об'єдналися По ОТГ обсяг додатково одержаних доходів складає 39.1 млн. грн. за станом на 1 липня 2018 року (рис. 1) [7].

Зростання доходів бюджетів об'єднаних громад ще раз підтверджує, що вони обрали правильний шлях для розвитку, ставши активними учасниками реформи місцевого самоврядування. Фінансова децентралізація забезпечила цим громадам можливість вирішити ті питання, які не вирішувалися роками через брак коштів. Реформа працює і дає позитивні результати.

Не виконано планові показники за І півріччя 2018 року лише в Калинівській ОТГ, виконання складає 99.3\% (-320,3 тис грн.) внаслідок неврахування термінів зарахування платежів при формуванні помісячного розпису.

Одночасно перевиконання понад $20 \%$ ставить під сумнів обгрунтованість формування помісячних розписів (Студенянська ОТГ, Немирівська ОТГ, Дашівська ОТГ, Бабчинецька ОТГ, Джулинська ОТГ, Ковалівська ОТГ, Мурафська ОТГ, Глуховецька ОТГ, Росошанська ОТГ, Новогребельська ОТГ).

Не виконано планові показники за І півріччя 2018 року лише по Калинівській ОТГ, виконання складає $99.3 \%$ (-320,3 тис грн.) внаслідок неврахування термінів зарахування платежів при формуванні помісячного розпису.

Одночасно перевиконання понад $20 \%$ ставить під сумнів обгрунтованість формування помісячних розписів (Студенянська ОТГ, Немирівська ОТГ, Дашівська ОТГ, Бабчинецька ОТГ, Джулинська ОТГ, Ковалівська ОТГ, Мурафська ОТГ, Глуховецька ОТГ, Росошанська ОТГ, Новогребельська ОТГ). 


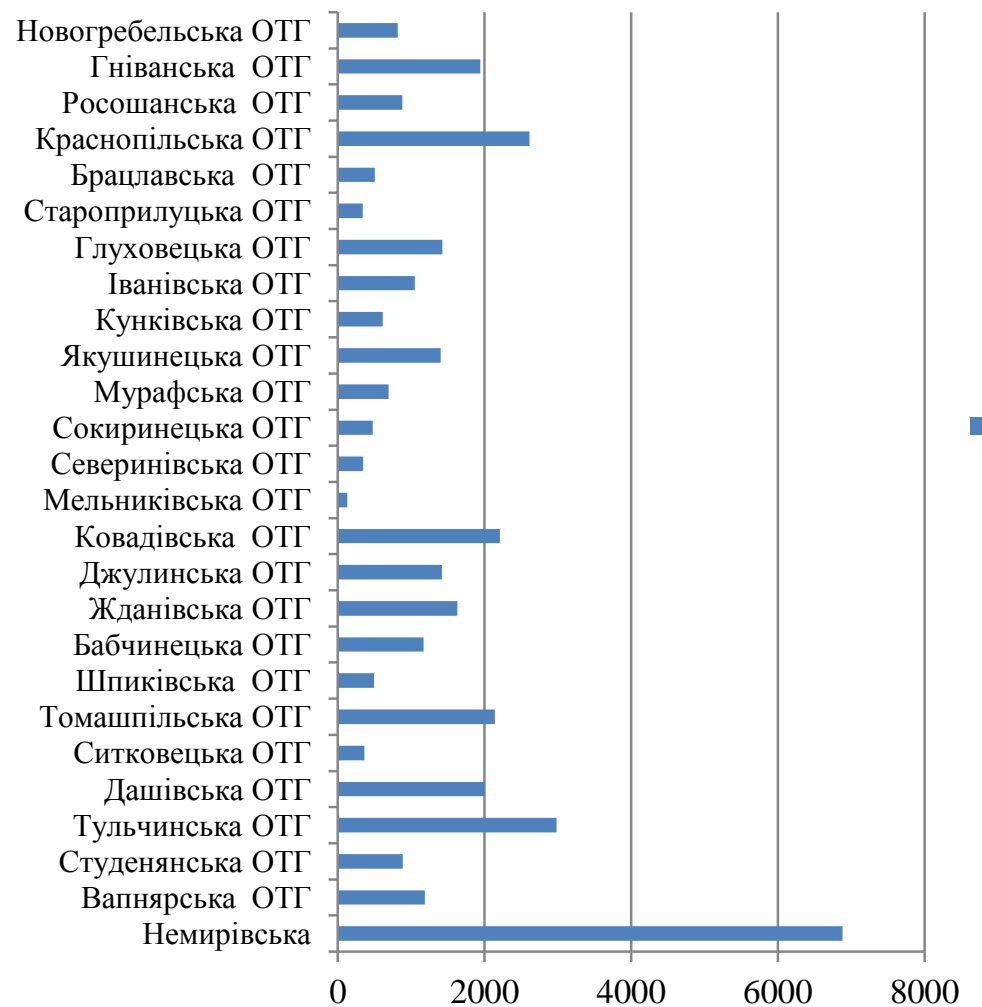

http://efm.vsau.org/

Надходження до загального фонду місцевих бюджетів ОТГ за І півріччя 2018 року, тис.грн

Рис. 1. Надходження до загального фонду місцевих бюджетів ОТГ Вінницької області за I півріччя 2018 року, тис грн.

\section{Дюерело:[9]}

Загальні темпи зростання загального фонду бюджету об’єднаних територіальних громад складають $127 \%$. За платежами найбільший обсяг зростання традиційно спостерігається за надходженням податку на доходи фізичних осіб - 33,4 \%. Із розрахунку надходження податку на доходи фізичних осіб на 1 мешканця, лідером є Жданівська ОТГ - 2012 грн., Томашпільська ОТГ - 1781 грн., Тульчинська ОТГ -1709 грн., Оратівська ОТГ - 1657 грн. Найнижчий показник Сокиринецька ОТГ - 296 грн., Шпиківська ОТГ - 308 грн., Мурафська ОТГ - 341 грн., Мельниківська ОТГ - 476 грн., Дашівська ОТ - 479 грн.

Низький рівень надходження основного бюджетоутворювального платежу свідчить про необхідність залучення інших резервів збільшення фінансової спроможності громади, у тому числі шляхом залучення інвестицій, реалізації прав на вільні земельні ділянки для розміщення потужностей підприємств та створення додаткових робочих місць. Структура надходжень залишається практично без змін. - 60 \% надходжень до загального фонду бюджету ОТГ формується за рахунок податку на доходи фізичних осіб, за рахунок плати за землю $13 \%$, податку на нерухомість лише $1 \%$, єдиного податку $-15 \%$, акцизного податку $-8 \%$.

Факторами визначення фінансової спроможності ОТГ залишаються [6]:

1) власні доходи на одного мешканця (співвідношення обсягу надходжень власних доходів до кількості мешканців відповідної ОТГ);

2) динаміка надходжень місцевих податків і зборів у 2018 році, порівняно з 2017 роком;

3) рівень дотаційності бюджетів (співвідношення обсягу базової чи реверсної дотації до загальної суми доходів ОТГ без урахування субвенцій з державного бюджету);

4) питома вага видатків на утримання апарату управління у фінансових ресурсах ОТГ (питома вага видатків на утримання апарату управління органів місцевого самоврядування в сумі власних доходів загального фонду).

За підсумками 6 місяців 2018 року середній показник надходжень власних доходів на 1-го мешканця по 34-х ОТГ області збільшився на 967,5 грн (+50,2\%) та склав 2 894,9 грн (у тому числі: по 21-й ОТГ, утвореній у 2015-2016 роках цей показник зріс на 27,9\% та становить 3 055,3 грн, а по 13-ти утворених у 2017 році - у 2,8 рази і становить 2541,3 грн).

Бюджетне законодавство більшості розвинутих країн побудоване на основі принципу єдиного (загального) фонду бюджету - кошти від усіх надходжень за визначенням не повинні мати цільового призначення. Це дає значну фінансову автономію місцевій владі та гнучкість в реалізації 
бюджетної політики. Щодо динаміки надходжень місцевих податків і зборів за 6 місяців 2018 року порівняно $з 6$ місяцями 2017 року, то найвищий темп зростання цих надходжень спостерігається в бюджеті Бабчинецької ОТГ - у 1,8 разів, найнижчий рівень - по Сокиринецькій ОТГ, де надходження зменшилися на 4,9\%.

Варто відзначити, що підвищення ролі місцевих податків і зборів, досягнення їхньої максимально можливої мобілізації повинно бути одним із пріоритетних завдань для органів місцевого самоврядування. Це, відповідно, сприятиме посиленню фінансової стійкості та самостійності місцевих бюджетів, ефективності використання наявного фіскального потенціалу відповідних територій i, як наслідок, покращання рівня та якості послуг, що надаються жителям громад. Формування значної частини власних доходів місцевих бюджетів - у прямій залежності від того, наскільки ефективно органи місцевого самоврядування зможуть організувати весь комплекс робіт із запровадження та мобілізації місцевих податків і зборів.

Дотація - це безвідплатна, безповоротна допомога з бюджету вищого рівня бюджету нижчому, яка не має цільового характеру та надається у випадку перевищення видатків над доходами. У Державному бюджеті України можуть передбачатися такі дотації місцевим бюджетам:

- базова дотація;

- додаткова дотація на компенсацію втрат доходів місцевих бюджетів внаслідок надання пільг, встановлених державою;

- інші додаткові дотації.

Базова та реверсна дотації спрямовані на горизонтальне вирівнювання податкоспроможності територій. Базова дотація надається $з$ державного місцевим бюджетам, а реверсна дотація навпаки - передається з місцевих до державного бюджету. Це два протилежних за напрямом руху грошові потоки, що функціонують між державним і місцевими бюджетами.

Серед ОТГ області 22 громади отримують 3 державного бюджету базову дотацію, 9 перераховують реверсну дотацію. Найвищий рівень дотаційності у Мурафській громаді, у якої обсяг базової дотації у загальній сумі доходів становить $36,5 \%$. Це означає, що органи місцевого самоврядування ОТГ повинні здійснювати пошук шляхів для зміцнення фінансового потенціалу своїх територій. Також їхнім завданням $є$ підготовка привабливих інвестиційних пропозицій та створення робочих місць. Такі кроки дадуть змогу наростити доходи місцевих бюджетів і зменшити залежність від державного.

Надзвичайно важливим індикатором спроможності громади $є$ частка видатків бюджету. Видатки бюджету - кошти, спрямовані на здійснення програм та заходів, передбачених відповідним бюджетом.

Видатки місцевих бюджетів (ст. 70 БКУ) включають бюджетні призначення, встановлені рішенням про місцевий бюджет, на конкретні цілі, пов'язані з реалізацією програм та заходів, перелік яких визначено Бюджетним кодексом України [2].

За плановими показниками 2018 року станом на 01.07.2018 у загальному обсязі капітальних видатків Вінницької області частка видатків ОТГ складає $20 \%$, тобто майже на рівні міст обласного значення (з урахуванням міста Вінниці) та на 15, 6 \% більше ніж частка районів.

Питома вага видатків на утримання органів самоврядування надзвичайно важливий показник, який свідчить про рівень «проїдання» бюджетних коштів на ОМС, яке зазвичай свідчить про те, що незалежно від кількості населення громада зобов'язана утримувати значну кількість посадовців для забезпечення всього спектру муніципальних послуг. В окремих громадах цей показник досяг вже загрозливого рівня - Мельниківська ОТГ - 56,1 \%, Мурафська ОТГ - 36 \%, Северинівська ОТГ - 50,9\%.

При більшій фінансовій спроможності бюджету частка видатків на утримання апарату управління буде меншою, оскільки такі витрати (без урахування витрат капітального характеру, пов'язаних із утриманням органів управління) мають відносно усталену величину. Тому в бюджетах із більшим ресурсом витрати на апарат управління у відсотковому вираженні є меншими. Внаслідок цього, такі громади мають можливість спрямувати більше коштів на розвиток своїх територій.

Для кожної ОТГ доцільним є встановлення власних обов'язкових процедур публічності і прозорості витрачання бюджетних коштів, які б робили зловживання неможливими, або, принаймні, доволі складними [11].

За словами І. Святної, експерта 3 місцевих фінансів Вінницького ЦРМС, органам місцевого самоврядування ОТГ рекомендується [9]:

- із метою збільшення фінансової спроможності громадам необхідно активно працювати над приєднанням навколишніх територіальних громад, що збільшити кількість населення, площу 
території та зменшує ризики невиконання бюджету та залежність від одного - двох бюджетоутворюючих платників;

- вживати заходи $з$ економії бюджетних коштів, спрямовувати видатки на першочергові потреби, оптимізувати структуру та чисельність виконавчих органів рад, виважено підходити до розмірів стимулюючих виплат, придбання меблів, обладнання, транспортних засобів;

- провести аналіз формування дохідної частини, вивчити можливість збільшення ставок по окремих видах платежів та категоріях платників, враховуючи як необхідність розвитку територій та залучення інвестицій, так і забезпечення життєдіяльності території громади.

- скасувати необгрунтовані пільги з місцевих податків.

Заради ефективного планування дохідної частини бюджетів ОТГ та реальних можливостей з іï розширення, органам місцевої влади необхідно співпрацювати 3 фіскальними органами 3 питань: визначення кількості осіб, що сплачують податки; обсягу їх нарахувань; забезпечення вчасного і повного виконання платниками податків своїх податкових зобов'язань; рівня добровільного виконання платниками вимог податкового законодавства; вивчення стану платіжної дисципліни; виявлення та залучення до сплати роботодавців та громадян із метою запобігання сплати заробітку в «конвертах» тощо [11].

Висновки. Бюджет $є$ регулятором економіки, що відображає обсяги необхідних державі фінансових ресурсів, визначає конкретні напрями використання коштів, спрямовує фінансову діяльність держави. Бюджет впливає на соціально-економічні процеси шляхом вироблення бюджетної політики використовуючи бюджетний механізм.

Нова модель фінансового забезпечення місцевих бюджетів і міжбюджетних відносин докорінно змінила бюджетну систему України та стала суттєвим кроком у проведенні реформи місцевого самоврядування і територіальної організації влади. На теперішній час в рамках реалізації Концепції реформування місцевого самоврядування та територіальної організації влади в Україні проводиться активна робота 3 формування спроможних територіальних громад. Бюджети ОТГ, що створюються згідно із законом і перспективним планом формування територій громад, мають прямі міжбюджетні відносини з державним бюджетом. У результаті буде забезпечено виконання одного з напрямків реформи міжбюджетних відносин - перехід від триступеневої до двоступеневої бюджетної системи.

Важливою проблемою, наявність якої стримує ефективність механізму формування i виконання бюджетів усіх рівнів в Україні, $\epsilon$ перевищення видатків бюджету над його надходженнями. При цьому дефіцит властивий як державному бюджету, так і місцевим бюджетам, а його негативний вплив виявляється в недофінансуванні таких життєво важливих галузей, як охорона здоров'я, освіта, житлово-комунальне господарство і соціальна сфера. Суттєвим є і той факт, що в Україні штучно створено значний прихований дефіцит місцевих бюджетів, ліквідувати який не можуть навіть трансфертні кошти, що надаються 3 державного бюджету. Особливість бюджетної системи України пов'язана з необхідністю застосування ефективних методів управління бюджетними ресурсами на рівні регіонів.

\section{Список використаних джерел}

1. Артус M.M., Хижа H.M. Бюджетна система України. URL: http://www.infolibrary.com.ua/booksbook122.html.

2. Бюджетний Кодекс України від 08.07.2010 р. №2456-VI Відомості Верховної Ради України. URL: http://zakon.rada.gov.ua.

3. Васильєва Н. В., Гринчук Н. М., Дерун Т.М., Куйбіда В.С., Ткачук А.Ф. Місцевий бюджет і фінансове забезпечення об’єднаної територіальної громади. Навчальний посібник. Київ.2017. 119 с.

4. Далєвська Т. Бюджетна децентралізація: передумови та напрями реалізації. Світ фінансів. 2016. Випуск 1. С. 149-159.

5. Про Державний бюджет Украӥни на 2018 рік. Закон Украӥни від 07.12.2017 № 2246-VIII. URL: http://search.ligazakon.ua.

6. Казюк Я. Експертний аналіз бюджетів ОТГ по кожній області - результати 9 місяців. URL:https://decentralization.gov.ua/news/10218.

7. Міністерство фінансів України Доходи бюджету за січень-червень 2018 року. URL: https://www.minfin.gov.ua/uploads/redactor/files.

8. Пелехата О.В. Бюджет розвитку як інструмент сільської територіальної громади в реалізації бюджетної політики економічного зростання. Соціально-економічні проблеми сучасного періоду в Україні. Львів, 2013. Випуск 6(104). С. 357-361.

9. Свята І. Про стан виконання місцевих бюджетів ОТГ Вінницької області за перше півріччя 2018 року Вінницький підрозділ Центральної установи. Центр розвитку місцевого самоврядування. URL: http://lgdc.org.ua/branch/2/pro-stan-vykonannya-miscevyh-byudzhetiv-otg-vinnyckoyi-oblasti-zapershe-pivrichchya-2018. 
10. Старостенко Г.Г., Булгаков Ю.В. Бюджетна система. Навчальний посібник. Київ, Центр навчальної літератури. 2006. 240с.

11. Овчаренко Т. Особливості формування та виконання бюджету об'єднаних територіальних громад. URL: http://icps.com.ua/ assets/uploads/images/images/eu/t_ormuvannya_vikon_budjet_final.pdf.

12. Pronko L., Samborska O., Kolesnyk T.V. Activities of united territorial communities as a body of local government in the conditions of power decentralization in Ukraine. Baltic Journal of Economic Studies. Volume 4, Number 2. Riga, Publishing House «Baltic Publishing».

\section{References}

1. Artus M.M., Huza N.M. Budzetna systema Ukraine. URL: http://www.infolibrary.com.ua /booksbook 122.html [in Ukrainian].

2. Budzetnuy Kodeks Ukraine. Kodeks Ukraine 08.07.2010 № 2456-VI. URL: http://zakon.rada.gov.ua [in Ukrainian].

3. Vasyleva N.V., Hrynchuk N.M., Derun T.M., Kuybida V.S., Tkachuk A.F. Mictsevuy budzet i finansove zabezpechenya obyednanoyi terytorialnoyi gromadu. Kiev. 2017. P. 119 [in Ukrainian].

4. Dalevska T. Budzetna decentralizatsia: peredumov ta napryamu realizatsiyi. Svit finansiv. 2016. №1. pp.149-159 [in Ukrainian].

5. Zakon Ukraine 07.12.2017 №2246-VIII. Pro derzavnuy budzet Ukraine na 2018. Verhovna Rada Ukraine. URL: http://search.ligazakon.ua [in Ukrainian].

6. Kazyuk YA. Ekspertnuy analiz budzetiv OTG po kozniy oblasti - rezultatu 9 month. URL: https://decentralization.gov.ua/news/10218 [in Ukrainian].

7. Ministry finance Ukraine Dohodu budzetu za january-july 2018 roku. URL: https://www.minfin.gov.ua/uploads/redactor/ [in Ukrainian].

8. Pelehata O.V. Budzet rozvutky yak instrument silskoi terytorialnoi gromadu v realizatsyi budzetnoy police ekonomichnogo zrostan'ya. Societ-ekonomy problem suchasnoho periodu v Ukraine. Lviv, 2013. 6 (104). pp 357-361 [in Ukrainian].

9. Svata I. Pro stan vukonanya mistsevuh budzhetiv OTG Vinnytskoy oblasti za pershe pivrichya 2018 roku. URL: http://lgdc.org.ua/branch/-2018 [in Ukrainian].

10. Starostenko H.H., Bulhakov YU.V. Budzetna systema. Navchal'nuy posibnuk. Kiev. Centr navchalnoyi literatury. 2006. $240 \mathrm{p}$ [in Ukrainian].

11. Ovcharenko T. Osobluvosti formuvan'ya ta vukonan'ia budzetu obyednanuh terytorialn'uh gromad. URL: http://icps.com.ua/assets/uploads/images/.pdf [in Ukrainian].

12. Pronko L. Activities of united territorial communities as a body of local government in the conditions of power decentralization in Ukraine. Pronko L., Kolesnik T., Samborska O. Baltic Journal of Economic Studies. Volume 4, Number 2. Riga. Pablishing House Baltic Publishing [in Latvia].

\section{Інформація про авторів}

ПРОНЬКО Людмила Миколаївна, к.е.н., доцент кафедри адміністративного менеджменту та альтернативних джерел енергії, Вінницький національний аграрний університет ( 21008 , м. Вінниця, вул. Сонячна, 3, e-mail: pronkoL@ukr.net).

СЕМЕНЕНКО Віктор Васильович, кандидат наук державного управління, доцент кафедри адміністративного менеджменту та альтернативних джерел енергії Вінницького національного аграрного університету ( 21008, м. Вінниця, вул.. Сонячна, 3, e-mail: pronkoL@ukr.net).

PRONKO Lyudmila, $\mathrm{PhD}$, associate professor, Department of administrative management and alternative energy sources, Vinnitsa National Agrarian University (21008, Vinnitsa, 3, Soniachna str., email: pronkoL@ukr.net).

SEMENENKO Viktor, $\mathrm{PhD}$, associate professor, Department of administrative management and alternative energy sources, Vinnitsa National Agrarian University (21008, Vinnitsa, 3, Soniachna str., email: pronkoL@ukr.net).

ПРОНЬКО Людмила Николаевна, к.э.н., доцент кафедры административного менеджмента и альтернативных источников энергии, Винницкий национальный аграрный университет (21008, г. Винница, ул. Солнечная, 3, e-mail: pronkoL@ukr.net).

СЕМЕНЕНКО Виктор Васильевич, к.н.гос.управл, доцент кафедры административного менеджмента и альтернативных источников энергии, Винницкий национальный аграрный университет (21008, г. Винница, ул. Солнечная, 3, e-mail: pronkoL@ukr.net).

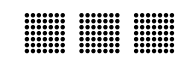

